\title{
Correlation linguocultureme human within east Russian, Ukrainian and Belarusian languages: comparative analysis
}

\section{[Реляция лингвокультуремы человек в русском, украинском и белорусском языках: компаративный анализ]}

\author{
Tetiana M. Mishenina - Larissa S. Dsevickaya
}

\section{DOI: 10.18355/XL.2017.10.04.25}

\begin{abstract}
Аннотация
Публикация посвящена исследованию функциональных и структурносемантических реализаций лингвокультуремы человек в восточнославянских языках на основе лингвокультурных сопоставлений (процедуры выявления общностей и различий в языках и культурах различных лингвокультурных сообществ), которые позволяют основательное изучение лингвокультуремы на основе компаративных параметров. Исследование позволяет также осуществление адекватного перевода исследуемой лингвокультуремы с учетом фонового культурного фонда, динамики развития семантического значения лексемы в соответствии с полевыми релятивными ассоциатами, а также с учетом развития сфер социокультурной действительности (не только лингвофилософской, психолого-педагогической, но и экономической, юридической), которая представлены такими вариантами, как: лицо / личность / душа // сердие. Результаты наблюдений над структурно-семантическими реализациями лингвокультуремы человек могут быть использованы при лингвокультурологических сопоставлений; проведении син- и диахронических лингвистических исследований; изучении динамики изменения значения лексемы человек в современных сферах общества и отображения дополнительных значений на уровне кодификации в национальных словарях восточнославянских языков.

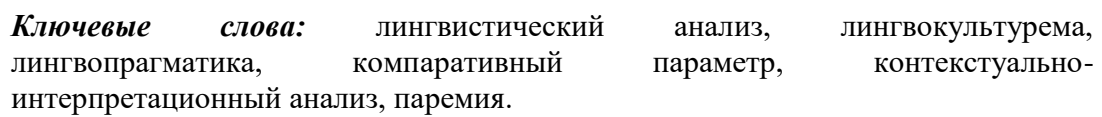

\section{Введение}

Объектом изучения лингвокультурологии как интегративной науки является лингвокультурема, которая аккумулирует как языковые представления, так и экстралингвистическую информацию, в исследовании которой применяют новейшие подходы, используя достижения смежных дисциплин (психолингвистики, культурологии, когнитивной лингвистики, теории информации). К категориальному аппарату лингвокультурологии отнесены также фоновые знания, которые реализуют информацию национальнокультурного характера, требующие лингвокультурологический комментарий, но могут быть переведены на другие языки и сопоставлены на уровне семантических реализаций.

Актуальность публикации обусловлена в первую очередь развитием теории лингвокультурологии на основе тесной взаимосвязи как языковой материи, так и динамики культурного развития. Кроме того, культурологическая интерпретация лингвокультуремы предусматривает также динамику аксиологической парадигмы в структуре языковой личности, которая является представителем определенной лингвокультуры. Процесс межкультурной коммуникации предусматривает также рассмотрение вопроса о стереотипизации, которая отображает не только ментальные характеристики этноса, но и представляет языковую картину мира как систему 
лингвокультурологических закономерностей восприятия предметов, явлений в рамках контрастивной лексики (Bartminski, 1985).

Лингвокультурологоическое рассмотрение языковой единицы предусматривает также выделение и последующий анализ уровней (уровень проявления эмоций и чувств, их интенсивность; уровень прагматического отношения к миру) менталитета. Исходя из того, что лингвокультурологические сопоставления конституируются на междисциплинарных методиках и подходах. В рамках философского подхода возможность покомпонентного семантического выделения в анализируемых лингвокультуремах сравниваемых языковых систем сущностного, общего в духовной жизни культур. Применение методик, касающихся культурологического комментария, позволяют акцентировать внимание на специфике мышления и поведения представителей лингвокультур на уровне таких дефиниций, как: «менталитет», «ментальность», «парадигма сознания», «картина мира», «стиль мышления» и т.п. На основе психологического подхода представляется возможным определять лингвокультурологические параметры языковой личности в рамках научного аппарата «установка», «ценностные ориентации», «стереотип», «концепт», «архетип», что позволяет рассматривать взаимосвязь личность / этнос в тесной взаимосвязи с амбивалентным направлением. Междисциплинарность в рассмотрении лингвокультуремы (в нашем исследовании - человек) как таковой предусматривает анализ в тесной взаимосвязи терминов «менталитет» и соотносительных - «ментальность», «национальный характер», «этнический менталитет». Как лингвокогнитивная категория, ментальность отображает посредством языковых средств автохтонность этнического мировосприятия, менталитет, как когнитивная категория, определяет стереотипную установку картины мира.

Соответственно, лингвокультурологические исследования предусматривают рассмотрение языковых единиц на уровне семиотической и ментальной систем, которые позволяют судить об уровнях национальной картины мира как специфической внутриязыковой реальности, функционирующей как в индивидуальном, так и в массовом сознании.

Следует отметить также, что вопрос об адекватности перевода эквивалентной и неэквивалентной лексики предусматривает тематическое разделение касательно групп анализируемых слов (например, рассматриваемый ракурс предусматривает культурологический комментарий мировоззренческого характера, так как лингвокультурема человек в контексте русской, украинской и белорусской лингвокультур предусматривает комментарий, касающийся религиозной семантики, которая имеет реализаци на уровне таких компонентов, как: монотеизм, христианство, молитва, образ Божий, душа, заповедь, грех, суд Божий и т.д.) (Skab, 2003; Yurkevych, 1990).

Исходя из того, что современные сферы социокультурной реальности - юриспруденция и экономика (социальная экономика) - представляют исследуемую лингвокультурему с позиции представительства личности, которая имеет определенные права и обязательства как гражданин. Таким образом, современный этап рассмотрения лингвокультуремы человек предусматривает также поуровневый компонентный анализ, который предполагает лингвистический анализ таких терминологических словосочетаний, как юридическая особа, субъект экономической деятельности.

\section{Теоретическая база исследования: состояние изученности проблемы}

Современная лингвистическая наука представлена

многочисленными исследованиями, которые интерпретируют лингвистический анализ, демонстрирующий как соотносительность, так и диаметральность

XLinguae, Volume 10, Issue 4, October 2017, ISSN 1337-8384, eISSN 2453-711X 
методик исследования. Применяемым является комплекс соответствующих исследовательских приемов, основанных прежде всего на использовании таких их механизмов (анализ семантики, выявления полевой дистрибуции и т.д.). В лингвистике ведущим, бесспорно, остается применение методик исследования лексем определенной тематической группы на основе анализа семантического пространства лексемы (анализ семантики языкового знака позволяет декодировать содержание соответствующего концепта, но который не ограничивается таким ракурсом, поскольку часть невербализованных признаков концепта остается невыявленной). Для более полного выявления структурных особенностей лексем рекомендуется использовать такие методики, которые конституируются на лингвистическом и денотативном подходах (Deetz, 1984 : 181; Gajda, $1992: 8-9)$.

Учитывая интеграцию таких наук, как лингвистика, лингвокультурологолия, психолингвистика, этнолингвистика, целесообразно применение культурологический, психолингвистических, собственно лингвистического и лингвокультурологического подходов к рассмотрению лингвокультуремы. Лингвокультурные сопоставления (процедуры выявления общностей и различий в языках и культурах различных национальных лингвокультурным сообществ) позволяют детально рассмотреть лингвокультуремы на основе компаративных параметров.

Лингвистический подход к анализу лингвокультурем предусматривает исследовательские приемы: 1) анализ семантики лексемы с помощью словарных дефиниций, изучение возможностей изменения расширения или сужения - семантической структуры слова в процессе исторического развития и в тексте; развития переносных значений; компонентный анализ, выделение дифференциальных сем (облигаторных, которые выделяют объект из класса подобных), энциклопедических сем (чрезмерных, превышающих достаточный уровень знаний) и импликативных (промежуточных); 2) выяснение этимологии лексемы; 3) выявление парадигматических отношений, синонимов, антонимов; 4) установление синтагматических возможностей лексемы, которые сочетаются с другими словами; потенциальной валентности; 5) изучение процесса вхождения слова во фразеологические единицы, анализ паремий, афоризмов, прецедентных текстов (при выделении лингвокультурологическое подхода эта группа относится непосредственно к нему); 6) выявление ассоциативного поля лексемы (если выделяется психолингвистический подход, эта методика входит в его состав); 7) контекстуально-интерпретационный анализ (Hirsch, 1987 : 25-26; Flower, 1995; Johnson-Laird, $1985: 85$ ).

В соответствии с типологическим принципом анализ структурносемантических особенностей лингвокультуремы (человек) предусматривает установление языкового типа для дальнейшей класификации, соответственно, задача сопоставления соотносительных компонентов заключается в сравнивании фактов (восточнославянских) языков с целью выявления сходств и различий в использовании языковых средств. Так как контрастивное изучение языков позволяет определяет особенности каждого из сопоставляемых языков, лексическое значение слова (человек) анализируем как сложный по своей природе феномен, аккумулирующий в себе многообразие языковых значений, соотносимых в рамках полевой структуры с коннотациями, которые отображаются в структуре лексического значения (когнитивное, или предметнологическое; грамматическое; коннотативное).

Денотативный подход является методически целесообразным в изучении картины мира, соответственно, предполагает анализ символов, закрепленных за определенными национально обозначенными объектами. 
Объект рассмотрения нашего исследования - лингвокультурема человек, которая на современном этапе развития социокультурной действительности претерпела ряд существенных семантических изменений и когнитивно-философское переосмысление.

\section{Методологические основы и методы исследования}

Классические и современные исследования механизмов овладения соответствующей культурой при изучении языка (Н. Арутюнова, А. Вежбицкая, Е.Верещагин, В. Жайворонок, В.Костомарова, В.Маслова, В.Красных, С.ТерМинасова, Г.Томахин, Д. Хаймс / N. Arutyunova, A. Vezhbytskaya, E.Vereshchahyn, V. Zhayvoronok, V.Kostomarova, V.Maslova, V.Krasnykh, S.TerMynasova, H.Tomakhyn, D. Khayms), формирования и развития языковой картины мира как способа отражения реальности в сознании человека сквозь призму языка и культуры (В.Воробьев, С.Кошарная, В.Красных, Г.Михайловская, Ю.Степанов, В.Телия / V.Vorob'ev, S.Kosharnaya, V.Krasnykh, H.Mykhaylovskaya, Yu.Stepanov, V.Telyya), осуществление поликультурной диалогизации (А.Бирбаум, Д.Вайс, Дж.Кивес, Р. Ладо, Ф.Лорд, Г.Раш, Д.Равен, К.Роджерс, Е. Сепір, М.Фридман / A.Byrbaum, D.Vays, Dzh.Kyves, R. Lado, F.Lord, H.Rash, D.Raven, K.Rodzhers, E. Sepir, M.Frydman) (Zhayvoronok, 2006; Lado, 1957 : 101-102; Sapir, 1978 : 157-158) позволяют основательно рассмотреть проблему адекватной интерпретации лингвокультурем на основе лингвистического и лингвокультурологического подходов в их тесной взаимосвязи и с учетом национальной специфики рассматриваемой эквивалентной / неэквивалентной их характеристики.

Лингвокультурологические сопоставления предусматривают рассмотрение этнопсихологического аспекта межкультурных различий (в рамках нашего исследования - религиозной специфики национального мировидения, базовых ценностей национальных культур и их соотношений с общечеловеческими достояниями, особенности этнических стереотипов, в целом специфика менталитета и национального характера.

Исходя из того, что соотношение значений языковых единиц с концептами лингвокультуры и общими характеристиками концептосферы является детерминированным, своеобразие языкового отражения мира как специфики различных уровней языковой системы предусматривает реализацию культурных коннотаций, оценочные характеристики которых восходят к аксиологической системе сопоставляемых культур, а также соотносительных культур, которые представляют современную поликультурную языковую картину мира (интерпретирующую способ этнического мышления об окружающей действительности, а также позволяющую классифицировать систему представлений об реальности на уровне тематических групп (материальная / духовная культура; земная / астрономическая картина; религиозное мировоззрение); определяет модельные рамки концептуализации действительности (в контексте нашего исследования речь идет об антропологической картине мире, где концепт человек составляет семантическое ядро).

Анализ лингвокультуремы человек предусматривает применение принципа диференциации языковой картины мира (значения слов) и концептуальной картины мира (понятие). Поскольку языковая картина мира является более дифференцированной и такой, которая отображает изменения в коннотативных реализациях рассматриваемого денотата (человек), концептуальную картину, которая является непосредственным отображением понятийного аппарата мировоззрения представителя определенной лингвокультуры. При лингвокультурологических сопоставлениях следует

XLinguae, Volume 10, Issue 4, October 2017, ISSN 1337-8384, eISSN 2453-711X 
учитывать как заполненные уровни, так и фрагментарные сопоставляемые языковые сегменты.

Следует отметить, что терминологические сочетания «картина мира»и «модель мира» соотносятся, в то же время следует учитывать такую специфическую особенность дефиниции «модель», как понятие условной схемы, своеобразной «матрицы» построения объектов реального мира, которые более точно указывают на структурное описание мира (в контексте нашего исследования - модели антропоцентрической). Если говорить о дефиниции «картина», то следует прежде всего принимать во внимание целостное представление об окружающей реальности. Следовательно, в нашем исследовании картина мира интерпретируется как восприятие окружающего мира современным человеком - особой/личностью/гражданином - и отражение этого восприятия в изучаемой лексико-семантической системе; модель мира рассматриваем через систему концептов, которая может быть истолкована как результат творческого осмысления этих знаний о мире и о человеке как центре этого мира.

Восточнославянское паремиологическое пространство определяется как структруированная в соответствии с ведущими речевыми функциями совокупность устойчивых словосочетаний, отображающих этносознание; национально-культурный компонент паремического значения позволяет выявлять смыслы, детерминируемые взаимодействием национального и культурного компонентов семантической структуры образной языковой единицы. При рассмотрении современного корпуса паремиологии структурносемантические особенности фразем интерпретируются в связи с их этнокультурной спецификой и культурной универсальности паремий, служащих средством трансляции культурно-исторического опыта этноязыкового сообщества. Анализ скрытых механизмов взаимосвязи, существующей между внутренней формой, значением, смыслом, мотивацией, коннотацией языковых единиц и их когнитивными корреляциями, позволяет объективировать концептуализацию и категоризацию социокультурной действительности.

Алгоритм рассмотрения восточнославянского паремиологичного дискурса предусматривает следующую процедуру: 1) выявление дискурсивного потенциала паремий как прецедентных единиц; 2) когнитивно-прагматическое моделирование паремийной семантики; 3) учет специфики паремийной репрезентации элементов языкового сознания; 4) выделение национальнокультурного компонента паремийных значений; 5) выявление ценностных акцентов паремийных семантики.

Цель публикации - раскрыть алгоритм лингвистического анализа лингвокультуремы человек на основе компаративных параметров; проследить с позиции диахронии развитие ее значения.

Методы исследования: Теоретические (анализ психологической, лингвофилософской и языковедческой литературы) собственно лингвистические (компонентный и этимологический анализ).

\section{Результаты и дискуссия}

На современном этапе развития «человек» понимается как биологическое существо, наделенное членораздельной речью, способностью мыслить, создавать и использовать орудия труда» (Fylosofskyy slovnyk Averyntsev, 1989 : 560). В рамках номинации «субъект права», «субъект предпринимательской деятельности» выделяются такие характеристики: 1) лицо как участник правового процесса; 2) лицо как субъект преступления; 3) лицо как участник судебного процесса; 4) лицо в сфере имущественных правоотношений и семантическая группа специалиста юридической деятельности. 
На уровне дефиниции современные толковые и специальные (юридические, экономические, психологические) национальные словари русского, украинского и белорусского языков представляют такие обобщения:

1. «Лицо - человек как субъект, имеющий индивидуальные интеллектуальные и другие признаки и осознает себя членом общности таких же субъектов» (Velykyy tlumachnyy slovnyk, 2007; Ozhehov, 2010; Fylosofskyy slovnyk Averyntsev, 1989 : 683) - совокупность черт, качеств, свойств определенному лииу.

2. «Лицо - это любая из следующих лиц: субъект хозяйствования юридическое лицо ...; физическое лицо, осуществляющее деятельность, относящуюся согласно законодательству к предпринимательской» (Verbenyets, 2003 : 5-6; Naukovo-praktychnyy komentar Banchuk, 2013 : 855) - совокупность черт, качеств, свойств определенному лииу.

Лингвокультурема человек в своем семантическом объеме реализует такие коннотативные характеристики гражданина: обеспечение объективных составляющих юридической / законной // противозаконной; экономической деятельности в пределах определенной страны. Фактически, можно утверждать, что коннотат правда в смысловой структуре лингвокультуремы человек экстраполируется в такие смысловые параметры с позиции юриспруденции (в качестве субъекта юридического / хозяйственной деятельности), как: а) максимальное соответствие нравственным критериям; б) проявление истинности при анализе юридической / противоправного действия (социальнополитические, экономические и субстанциально-личностные аспекты); в) обеспечение соразмерности осуществления противозаконного действия / совершения преступления и наказания; г) следование моральному кодексу (культуры) общества; д) обязательность для каждого члена общества выполнения моральных установок.

Лингвокультурологический анализ паремий восточнославянских языков последовательно отображает изложенные выше антиномии на уровне понятий:

1. Добро / Зло: рус. Деньги смогут много, а правда все; За добро злом не платят (Byrykh, 1998); укр. Брехня не введе в добро; В кому правди немає, в тому добра мало; Де добра немає, там не шукай правди (Prysliv'ya i prykazky Myshanych, 1989).

2. Правда / Кривда (Неправда): рус. Неправдою жить - не хочется, правдою жить - не можется; Правда в лаптях, а кривда, хоть и в кривых, да в canогах (Byrykh, 1998); укр. Засип правду золотом, затопчи ї̈ в бруд, а вона все вийде назовні; Правда кривди не любить (Prysliv'ya i prykazky Myshanych, 1989). Выделенный уровень позволяет констатировать такие критерии: а) мудрость (немногословность): укр. Правда не речиста; б) единичность (неповторность) укр. Правда одна, а брехні скільки завгодно; в) истинность (суровость закона) укр. Правда сама себе очистить; Правда світліша сония; г) истинность (сила) укр. Правда силу народить; д) истинность (вечность) укр. Правда стара, та не вмирає, брехня молодший, та недовго поживає; Все минется, одна правда залишиться (Prysliv'ya i prykazky Myshanych, 1989).

3. Правда как моральный императив (определение линии поведения): рус. Богу молись, а в делах не плошись; Богу молись, а добра ума держись; Богу молись, ак берегу гребись; Богу молися, а сам не пломай (Russkye poslovytsy V. Anykyn, 1988) // укр. Брехня людину не прикрашає; Збрешеш - не помреш, так вперед не повірять; I суворий, та правдивий, і ласкавий, так брехливий; Хлібсіль ̈̈ж, а правду завжди слухай (Prysliv'ya i prykazky Myshanych, 1989) // белор. На Бога спадзявайся, але й сам старайся, Бог то бог, але і сам не будзь жох (Lepeshay̆, 2014).

XLinguae, Volume 10, Issue 4, October 2017, ISSN 1337-8384, eISSN 2453-711X 
Отдельное внимание следует обратить на паремии, которые ретранслируют религиозные представления представителей восточнославянских лингвокультур. По нашим наблюдениям, лингвокультурема человек интерпретируется сквозь призму коннотаций Бог (правда), жизненный путь (закон / заповедь / моральный кодекс): рос. Правда у Бога, а кривда на земле; Кто повинился, того суди Бог; Бог правду видит (Byrykh, 1998; Russkye poslovytsy V. Anykyn, 1988) // укр. Бог не в силі, а в правді; Бог любить правду; Не в силі Бог, а в правді; Хто ламає слово, той віру ламає, той душу ламає, той Бога ламає (Prysliv'ya i prykazky Myshanych, 1989) // белор. Бог не ияля, бачыцьь круияля, Бог не слухае, што свіння рухае (Lepeshay̆, 2014).

Приведем короткий культурологический комментарий демонстрируемой когнитивной корреляции человек / Бог. Предметом лингвокультурологического анализа с позиции монотеистического мировоззрения является христианская молитва, которая отражает сакральный процесс общения души как бессмертной сущности человека с Богом, когда философия жизни выстраивается как своеобразная «драма человеческой жизни». Соответственно, приближения души к Богу определяется количеством благотворительных (богоугодных) дел (речь идет о тенденции экзистенциальноантропологической редукции философского знания) (Relihiyeznavchyy Kolodyi, 1996; Fylosofskyy Arab-Ohly, 1989).

Христианство решает проблему богоподобия человека, когда трагическое противоречие, направленное на решение и спасение составляет сущность «благой вести», а принцип гармонии противоположностей внутреннего, внешнего и социального миров - решается путем диалектическим: гармонии внутреннего мира человека в соответствии с заповедями Божьими: рус. Человек божий обшит кожей (Byrykh, 1998) // белор. Все мы люди Божьи (Akademichny zvod prykazok, 1976).

В этом контексте следует отметить и развитие лексикосемантической системы, обусловленное влиянием греческой христианской культуры. В результате взаимодействия $\mathrm{c}$ греческим языком в восточнославянском пространстве Древней Руси имели место лексические кальки, которые являются буквальными морфологическими кальками греческих

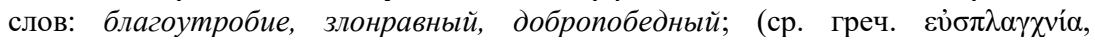

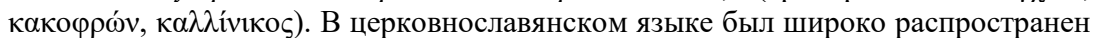
принцип калькирования, буквального перевода греческих слов (беззаконие (anomia), бездушие (apsykhia), богословие (theologia), совесть (syneidesis), согласие (symphonia), предтеча (prodromos), предатель (prodotes).

Словообразовательные кальки отображают существенные изменения в концепции, раскрывающей сущность человека, в основном является революционным переосмысление внутреннего мира: $б$ е $з$ - / б е с-: -божный (из греч. a-theos), -брачный (из греч. а-gaтоs), -вестный (из греч. а-delos), -гласный, -душный, -образничать, -смертие,; благо-: -вестие/-вестник, -верие, временный, -говение, -дарение, -детель, -деяние, -душие, -изволение, -лепие, надежный, -образие, -потребный, -приятный, -разумный, -родный, -словенце, стный, -стыня, -творение, -творец, -угоден, -утробен, -ухание, -хваление, -

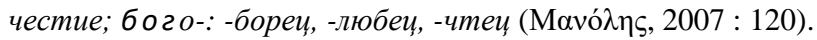

Религиозное мировоззрение представляет кардинально иную интерпретацию таких понятий, как жизнь / смерть. Если для языческого восприятия важным является тело и продолжение жизни тела в загробной жизни, то христианская позиция представляет в первую очередь жизнь как бытие души, смерть тела нивелируется в понятии бессмертной души, тогда как мертва душа является показателем настоящей смерти. Как пример, сравним паремии, которые отображают языческий и христианский миры, ср.: укр. 1) Нехай над ним земля пером; На другий світ дорога; Перебратися в інший світ; 
Білий світ; Пішов до чорта на шабаш; Душа одлетіла до пекла; Пішла душа на виринки; 2) Покликав Бог жнивувати на вічні жнива; Бог забрав до себе (Prysliv'ya i prykazky Myshanych, 1989).

Диалог с высшей силой в православном христианстве предусматривает также обязательное обращение к иконе (середньогреч. Eikón - образ, портрет), которая по своему художественному и технологическому решению должна передавать состояние внутреннего сосредоточения, важнейшей художественной деталью иконы, отображенной в своеобразном сочетании хроматической и линейной семантике, является также проявление духовного мира (божественный порядок, божественную благодать и покой преображенного, просветленного божественным светом образа) на уровне христианского мировоззрения (Yurkevych, 1990 : 72-74) (а) молитва позиционирует преимущество благословение Бога как Творца человека и жизни касательно просьбы удовлетворения жизненных потребностей; б) понятие жертвы приобретает значение духовного служения Богу для восстановления в себе образа Божия; в) концептуальной правдой обладает только Бог, открывает ее богоугодному человеку, актуализируя оппозиции праведность (совесть) / грех вера / безбожье; закон / благодать; отвлечение от Бога / раскаяние; при этом императивные формы являются установкой для человека; г) риторические вопросы библейского содержания побуждают к размышлениям над ситуацией; г) аллегорические высказывания подаются коррелятивно к аналогиям из повседневной жизни; д) притчи характеризуются глубокой метафоричностью и сложной образной системой: рос. Без веры Господь не избавит, без правды Господь не исправит; За Богом молитва не пропадает; Богу молись, крепись, да за соху держись; Богу молись, а к берегу гребись; Богу молись, а в делах не плошись (Byrykh, 1998; Russkye poslovytsy V. Anykyn, 1988) // укр. Світло в оселю від свічки, а в душі від молитви; Береженого Бог береже, а козака шабля стереже; Так буде, як Бог дасть (Prysliv'ya i prykazky Myshanych, 1989); белор. На Бога спадзявайся, але й сам старайся (Akademichny zvod prykazok, 1976).

Изложенное выше позволяет говорить о семантической многослойности лексемы, которая в том числе реализует дополнительное значение раскаяния как характеристики внутреннего мира человека, сочетающего духовно-религиозное осмысление праведных / неправедных поступков, когда рефлексия совершенного поведения и внутреннего состояния позволяет наметить новый жизненный путь, изменить социокультурное поведение, сформировать ценностные ориентации. Паремии восточнославянских языков отображают соотносительные параллели Бог (Суд Божий) / поведение / человек; имеют место реляции душа в смысле человек (Skab, 2003 : 94-95; Fylosofskyy Arab-Ohly, 1989; Yurkevych, 1990 : 85), а также суда Божия как высшего, что позволяет говорить прежде всего о ярко выраженной мировоззренчески-религиозной картины мира русского, украинского и белорусского лингвосообществ, автохтонность в восприятии девиантного (преступного / противозаконного) поведения, определяя такие действия как грех (отступничество):

1. Экзистенциально-религиозная интерпретация семантической составляющей суд (Божий) свидетельствует превосходство силы Бога, неотвратимость и справедливость наказания / милости: рус. Бог накажет, никто не укажет; Бог рассудит, да не скоро скажет (Byrykh, 1998; Russkye poslovytsy V. Anykyn, 1988) // укр. Суду Божого околицею не об'їдеш; Не нашим розумом, а божим судом (Prysliv'ya i prykazky Myshanych, 1989) // белор. Бог не роўна дзеліиь, Дай божа, каб усё было што нягожа, Дай божа ў добры час сказаць, а ўліхі (нядобры) намаўчаць (Akademichny zvod prykazok, 1976).

XLinguae, Volume 10, Issue 4, October 2017, ISSN 1337-8384, eISSN 2453-711X 
С позиции лингвофилософии, библейская правда отображена в Библейских установках, в которых человек должен воспринимать образ мира должного, с которым отчасти находится мирская реальность в конфликте; установки способствуют конструированию внутреннего мира / «иарства в душе человека», угодного, то есть правильного, Богу: «Господи! Путеводи мене у правді Твоїй, заради ворогів мойх; урівняй переді мною путь Твою» [Псалом 5]; «Бо Господь праведний, - любить правду; лице Його бачить праведника» [Псалом 10].

Паремии, связанные с интерпретацией библейских притч, функционируют в восточнославянских языках под влиянием Библии, хотя не во всех случаях она является первоисточником. Всем славянским языкам и греческому известна параллель к ветхозаветному изречению из Притчей: Много замыслов в сердие человека, но состоится только определенное Господом (Притча 19.21) / русская интерпретация Человек предполагает, а Бог

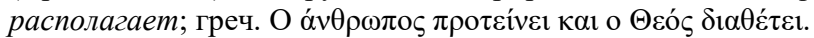

2. Реляция понятий противозаконное действие / греховное действие отображена в определенной степени на уровне императивных и назидательных конструкций: рус. Грех - греху рознь, с другим и сквозь землю провалишься; Каков грех, такова и расправа; Грех воровать, да нельзя миновать; Грех да напасть бороною ходит, кого зачепит; Грех сладок, а человек падок; Грех, что дуга вязовая: кониь в воде, середка наружу; Безгрешна человека на свете нет; Грешить легко - трудно каяться (Russkye poslovytsy V. Anykyn, 1988) // укр. Без віри Господь не позбавить, без правди Господь не виправить; Гріх не гріх, аби Бог простив; Де гріх, там і покута (Prysliv'ya i prykazky Myshanych, 1989).

Лингвистический анализ паремий с компонентом грех позволяет выделить следующие семантические маркеры:

а) квалитативный (несопоставимость мира реального и ирреального с преобладанием значимости последнего): рус. Грех с орех, ядро с ведро; Грех в орех, а нам ядрышки в рот; Грех не уложишь в орех; Один грешок - и тот с мешок (Russkye poslovytsy V. Anykyn, 1988) - приведенные паремии построены на противопоставлении малой - ореха - и большой форм (ведро / мешок), что можем объяснить видимой неприметностью совершенного: даже маленький проступок имеет негативные последствия, соотносительные со сравниваемыми формами в реальном мире;

б) актуализация на уровне причина / следствие противозаконного (небогоугодного) действия / поступка, обязательность исправления совершенного: рус. Мал грех, да велика причина; Мала причина, да грех велик; Один грех всю душу оскверняет (Russkye poslovytsy V. Anykyn, 1988);

в) социокультурный императив: Грех при всех - двойной грех (Russkye poslovytsy V. Anykyn, 1988).

Восточнославянский паремиологичный фонд отображает корреляцию моделирования жизненного пути с Божьими заповедями: рос. Бог путь торует правдой (Russkye poslovytsy V. Anykyn, 1988); Всякая дорога от Бога; укр. Добрий (потрібний) илях Бог править (Prysliv'ya i prykazky Myshanych, 1989).

Наблюдение за языковым материалом позволяет утверждать, что в восточнославянских языках маркер судьба трактуется в $60 \%$ согласно христианскому видению мироздания, ср.: судьба - ход событий, стечение обстоятельств, направление жизненного пути, которое отчасти зависят от желания, воли человека; // условия жизни; жизненный путь и то, что на нем происходит (Velykyy tlumachnyy slovnyk, 2007 : 315; Ozhehov, 2010); судьба определенность событий и поступков человека; каузальная детерминация (Velykyy tlumachnyy slovnyk, 2007 : 635; Ozhehov, 2010). Паремии содержат когнитивную информацию о судьбе человека не столько предусмотренную, сколько направленную на морально правильную прожитую жизнь (Kronyk, 1993 
: 180-182), достижение свершений; такую, которая дает возможность человеку реализовать энергетическое творческое качество, которым он наделен (активизированы такие дополнительные семантические компоненты: определенность, достаточность, иеленаправленность, вера, судьбоносность): укр. Бог дасть долю і в чистім полю (Prysliv'ya i prykazky Myshanych, 1989); белор. І мая доля не шчарбатая (Akademichny zvod prykazok, 1976).

Когнитивно-прагматическая сущность лингвокультуремы человек в составе паремий реализует значение, соответствующее прагматичным установкам, реализует когнитивную функцию этноязычного сознания.

Как пример, могут быть такие паремии: рус. Что Бог ни даст: либо выручит, либо выучит (Russkye poslovytsy V. Anykyn, 1988) // укр. Бог дає й карає по правді (Prysliv'ya i prykazky Myshanych, 1989])// белор. Калі Бог не папусьціиь, свіння ня укусіть (Lepeshay̆, 2014).

Паремиологический корпус отображает этнокультурное сознание (выявленная способность паремий свидетельствовует об установках и стереотипах этноязыкового сознания; репрезентативный потенциал народных афоризмов в реализации речеизмыслительного стереотипа в ходе коммуникации; синкретизм самого понятия сознания, способствующий последовательному разграничению речевых образованиях, языковых фактов, семантических, лингвокогнитивных категорий и собственно когнитивных единиц).

Например, паремии рус. Что Бог ни даст: либо выручит, либо выlyчum (Russkye poslovytsy V. Anykyn, 1988) / укр. Що Бог не посилає, то до добра (Prysliv'ya i prykazky Myshanych, 1989) с позиции лингвокультурологии можно интерпретировать таким образом: (формулировка афористического значения (испьтание судьбы полезно человеку при любом исходе); прагматические установки (терпи, извлекай уроки из ситуации); когнитивные функции (стереотипизация заключения).

Общее значение приведенных паремий обозначает определенное закономерное согласно намеченного жизненного пути испытание, которое необходимо для души человека любого следствия. Прагматическая установка предусматривает выполнение императива: терпеть и усваивать жизненные уроки, приобретать опыт на основе переживания жизненной ситуации. Дискурсивная обусловленность смысла соответствует обобщению значения и стереотипизации жизненной ситуации [Bartminski 1985 : 74], воспринимаемой через сакральную детерминацию, что позволяет говорить о пониженной референции денотатов-компонентов и отсутствии конкретных хронотипных маркеров в структуре соответствующих паремий.

Современная психолингвистическая и философская мысль интерпретирует дефиницию человек в коррелятивной взаимосвязи с понятием душа, которая понимается как субстанция, имеющая право на осуществление правомочных действий, давать оценку общественному строю и представлять интересы общества. Констатируем детерминацию религиозномировоззренческой позиции статуса лица (Velykyy tlumachnyy slovnyk, 2007 : 94-95; Ozhehov, 2010; Relihiyeznavchyy Kolodyi, 1996; Fylosofskyy Arab-Ohly, 1989):

1. Бессмертная нематериальная основа человека, которая составляет сущность ее жизни и является источником психических явлений: рус. Отдать Богу душу (Russkye poslovytsy V. Anykyn, 1988) // укр. Віддати Богові душу (Prysliv'ya i prykazky Myshanych, 1989) // белор. Аддавацьь Богу душу (Akademichny zvod prykazok, 1976).

XLinguae, Volume 10, Issue 4, October 2017, ISSN 1337-8384, eISSN 2453-711X 
2. Внутренний психический мир человека, с его настроениями, переживаниями и чувствами. // Психологические особенности этноса вообще или конкретного этноса.

Выше изложенное позволяет сделать обобщение о том, что семантическая реляция людина // душа отождествляется со сосредоточением конструктивных / деструктивных эмоций; степень веры в высшую силу: рус. душа nоет (Ozhehov, 2010) // укр. душа співає (Velykyy tlumachnyy slovnyk, 2007) // белор. душа спявае; відсутність відчуттів (без душы) (Akademichny zvod prykazok, 1976).

3. Совокупность качеств, характерных определенной особе. // Человек как носитель тех или иных черт, качеств. // О человеке с прекрасными чертами характера.

Рассматриваемая реализация представлена определяющими маркерами, которые обозначают черты человека - душа / натура: рус. заячья душа // укр. заяча душа // белор. заечая (заячая) душа (боягузлива); рус. черная душа; укр. чорна душа; белор. чарнільная душа; рус. мертвая душа; укр. мертва душа; белор. мёртвая душа.

Заметим, что характеристика внутреннего мира человека с помощью ахроматических характеристик черный / бельй соотносится с антиномией добро / зло, древними политеистическими представлениями восточных славян: первыми божествами древнеславянского пантеона были боги Белобог и Чёрнобог (Lanovyk, 2001 : 76-77), которые олицетворяли светлые и темные силы.

Понятие светлой души на уровне христианского мировоззрения имеет основой древние представления восточных славян, которые представляли солнце (центральное небесное светило солнечной системы), как божество, которое имеет форму гигантского раскаленного шара и излучает свет и тепло. По народным представлениям, солнце - персонифицированное существо, с которым связано много легенд, поверий и обрядов; символ всевидящего божества; высшей космической силы; центра бытия и интуитивного знания; озарение; славы; величия; правосудия; Матери Мира; центра; Бога Отца Христа (Zhayvoronok, 2006; Lanovyk, 2001; Fylosofskyy Arab-Ohly, 1989).

В украинской и белорусской лингвокультурах наблюдаем божественные добронравные создания Солнще-Коляда, Журила, Ярила, Юрия. Народные сравнения представляют подобные ряда, которые имеют основой монотеизм: Глаз Божий, огненный несгораемый шар, большое колесо или круг, чело Божье, свеча, которую носят ангель. Мифологическое восприятие представляет солнце как живое существо (женщина, которая неподвижно стоит в воздухе; мужчина с лучезарным лицом, лучи которого освещает вселенную. Астронимная картина мира представлена родоводом: солнце и луна являются братом и сестрой / мужем и женой; звезды - их дети (Zhayvoronok, 2006 : 564566).

Российская лингвокультура представлена такими составляющими: Солние, Даждьбог. Народные сравнения, которые преобладают в восприятии представителей русской лингвокультуры, являются такие: Божий лик, небесное окно, каравай хлеба, колесо, всевидящее око. Согласно мифологическому восприятию солнце ездит на чудесной колеснице, которая запряженная четверкой белых златогривый лошадей с золотыми крыльями; солнечный свет образуется от огненного щита, который солнще возит с собой. Род в этносознании был представлен на таких уровневых соотношениях: Утренняя Заря - жена; Вечерняя Заря - сестра; Луна - брат.

С позиции лингвокультурологии констатируем трансмиссию языковых картин представителей украинской, русской и белорусской культур на как уровне сопоставления пантеонов славянских богов (солярное мировоззрение, 
поскольку древние славяне видели в солнце величественный источник тепла и света, от которого зависели их жизнь и процветание), так и монотестическое восприятие организации мира.

Нами установлено, что устойчивой в сочетаниях с лексемой душа является реляция душа / серце, которую также можем объяснить религиозномировоззренческим восприятием, в соответствии с которым сердие является транслятором чувств и воли человека, своеобразным вместилищем бессмертной субстанции - души, которая диалогизирует с Богом посредством молитвы:

- рус. душа / сердие болит / горит / заныла / кровью облилась / не лежит / не на месте / ноет / разрывается (Ozhehov, 2010);

- укр. душа / серие болить / горить / занила/ кров'ю облилась / не лежить / не на місиі / ниє / розривається (Velykyy tlumachnyy slovnyk, 2007);

- белор. душа / сэриа балічь; душа / сэриа гарыиь; душа / сэриа заныла; душа / сэриа крывёй абліваещиа (аблілася); душа / сэриа не ляжыць; душа / сэриа ляжыщь; душа / сэриа не на месцығ; душа / сэриа ные (ныла); душа / сэрияа разрываецица (рвецица) (Akademichny zvod prykazok, 1976).

Паремийная когнитивная интерпретация позволяет говорить о корреляции исследуемых семантических составляющих дуща / сердие, которые подтверждают такие компоненты, как: искренность (открытость), неподкупность, правдивость, ощущение правды / неправды: рус. а) Сердие - не лукошко: не прорежешь окошко; Сердчем не приманишь, так за уши не притянешь; б) Сердиу денег не дашь; в) Чует сердие и друга и недруга; Сердие - вещун: чует, где добро, где зло; Сердие душу бережет и душу мутит; Душа не стерпит, так сердие возьмет (Byrykh, 1998; Russkye poslovytsy V. Anykyn, 1988).

Исходя из наших исследований, эмоциональность представителей русской, украинской и белорусской лингвокультур определяется своеобразной эмоциональностю, соотносительной с повышенной эмпатией души, квалифицируемой как особое восприятие мира - кордоцентризм, которая проявляется в следующих характеристиках (восприятие себя как части природы; понимание согармонии внутрененного и внешнего миров; актуальная позиция эмпатии; понимание о космополитизме - соотношении и правильности организации элементов Вселенной) (Yurkevych, 1990 : 80-82). Философские труды П. Юркевича позволяют определить основные направления сопоставления менталитетов русского, украинского и белорусского народов («Сердце и его значение в духовной жизни человека, по учению слова Божия; «Разум по учению Платона»; «По поводу статей богословского содержания, помещенных в «Философском лексиконе» (критико-философские отрывки); «Мир с ближними как условие христианского общежития». Предлагаемая ученым философско-антропологическая концепция о сердце как определяющей составляющей человека, его физической и духовной жизни; с темой сердца в работах мыслителя тесно сопряжена тема любви «светильник и елей», что позволяет сделать вывод о том, что нравственность обусловлена метафизическим отношением любви сердца к добру.

Подход к сердцу как символу эмоционально-интеллектуальной волевой сущности личности, идущий от ветхозаветной традиции, свойственен христианской философии. Восточнославянская культура (на примере русской, украинской и белорусской лингвокультур) достаточно ярко раскрывает рассматриваемую тему. Отметим, что ближайшим предшественником П. Юркевича в ее разработке был украинский мыслитель Г.Сковорода (диалог «Начальная дверь к христианскому добронравию»).

XLinguae, Volume 10, Issue 4, October 2017, ISSN 1337-8384, eISSN 2453-711X 
В своих трудах П. Юркевич, разрабатывая концепцию кордоцентризма, обращается непосредственно к сочинениям греческих мыслителей.

4. библ. Жизнь. // Чувство, вдохновение, энергия.

Отдельное внимание обращаем на понятие зла, которое, как уже отмечалось, на дохристианском уровне олицетворял Чернобог; монотеизм представляет антиномию, которая на языковом уровне представлена антонимами Бог / дьявол, где поведение, касающееся божественного порядка, является абсолютно верным и богоугодным (светлая душа), дьявол символизирует только греховное поведение (черная душа): Силен черт, да воли нет; Раздел от Бога, а ссыпщина от черта (Byrykh, 1998).

Оксиморонное библейное сочетание Черный ангел иносказательно характеризирует также человека, который своими помыслами и поведением преступил заповеди.

Уникальную антропоморфическую интерпретацию представляет лингвокультурема ведьма (женщина, продавшая душу дьяволу). Народнопоэтическая интерпретация «темных сил» свидетельствовала о двоеверии (параллельном восприятии мира как моно- и политеистического, которые пребывали в тесной взаимосвязи): Н. Гоголь «Вечера на хуторе близь Диканьки», «Вий», Г. Квітка-Основ'яненко «Конотопська відьма», О. Стороженко «Відьма».

Паремии отображают коннотацию чорт как ультранегативную и несущую информацию о неприемлемом поведении, в императивных конструкциях - назидательную для человека или упреждающую для проявления злых сил: рус. Связался с чертом - пеняй на себя (Byrykh, 1998; Russkye poslovytsy V. Anykyn, 1988); укр. Щоб тебе чортяка вхопив!; Вискочив, наче чорт із мішка; Чорте! На груш, тільки мене не воруш! (Prysliv'ya i prykazky Myshanych, 1989).

Языческое восприятие понятия человек последовательно отобразилось в наивном понимании возможности взаимоотношений с представителями мира / антимира, которые воплотились в определенные законы магии: назвать, дать имя - значит дать жизнь, сделать частью реального мира; произнести слово означает вызвать присутствие названного им (с этим связан запрет «не вспоминать черта на ночь, чтобы не призывать»; магическая предикация устанавливает и актуализирует особые соотношения между явлениями; воспроизводимые заговоры противоречат законам причинно-следственной мышления: вместо причинности прослеживается аналогия, причем отношение аналогии часто устанавливается между несочетаемых с точки зрения «здравого смысла» явлениями.

Характеристика внутреннего мира и поведения человека, соотносимая с коннотатами чорт / ведьма, содержит такие дополнительные семантические реализации, как: гневливость, напыщенность, сварливость, злость, мстительность, коварность, продажность: рос. Никто беса не видит, а всяк его ругает; Черт не возьмет его, а Богу не надо; Сделка с чертом; Продал душу черту (Byrykh, 1998; Russkye poslovytsy V. Anykyn, 1988); укр. Дивиться чортом; У баби язик, як у чорта хвіст довгий; Відьмаиьке кодло (Prysliv'уа i prykazky Myshanych, 1989).

\section{Выводы}

Приведенные и проанализированы выше языковые репрезентации лингвокультуремы человек позволяют сделать следующие обобщения: 
- соразмерное распределение паремий восточнославянских языков в понимании лингвокультуремы человек сквозь призму таких маркеров, как: правда / Бог / рок / душа // сердие;

- определенная асимметрия в современном понимании лингвокультуремы человек на уровне маркеров лицо / личность / субъект права / субъект хозяйственной деятельности по сравнению с экзистенциальнорелигиозной интерпретацией;

- стилистическая функциональность рассматриваемых паремий с гипонимическим компонентом человек в восточнославянских языках является довольно широкой, реализует смысловые оттенки, которые соотносятся в большей степени с понятием «божественного», чем «человеческого»; тогда как современные отрасли (юриспруденция, экономика, психолого-педагогическая наука) представлены преимущество «человеческим» компонентом и соответствующим гуманитарным дискурсом;

- национальные словари русского, украинского и белорусского языков представляют по результатам статистики (проанализировано более 500 единиц) сопоставимый перевод, что можем объяснить тысячелетней историей, связанной с принятием православного христианства, а также определенным периодом политеизма, где пантеон славянских богов имел однородность на уровне антиномий добро / зло (солние, свет, день / зло, темнота, ночь);

- частотность использования в художественном и разговорном стилях описанной лингвокультуремы позволяет говорить об этнической стереотипизации, которая предусматривает рассмотрение соотносительных понятий человек / душа;

- актуальным является вопрос отображения темпоральной этносознания представителей восточнославянских лингвокультур с учетом религиозной и социокультурной детерминации (Рождество / Різдво, Благовещение / Благовіщення, Пасха / Великдень и т.п.);

- заслуживают внимания стилистические и лингвофилософские ресурсы адгерентных (которые употребляются вне евангельского контекста): Oт всего сердия / Від усього серия; ингерентных библейских фразем (вневременной (вечный) контекст): Всякое даяние благо; Вера без дел мертва (есть).

\section{Заключение}

Лингвокультурема человек охватывает коннотативные асоциаты, соотносимые с эквивалентной / неэквивалентной лексикой; паремиологическим фондом; эталонами коммуникации, стереотипы, символами; метафоры и образы языка; стилистический уклад языков; речевой этикет; на уровне морфологического выражения может быть представлена одним словом, словосочетанием или же целым текстом (отрывком из него), широко известным носителям языка.

Лингвокультурологический подход, применимый при рассмотрении лингвокультуремы человек, способствует: а) развитию языковой картины мира, культурологического мировоззрения представителей русской, украинской и белоруской лингвокультур в восприятии себя как носителя национальных ценностей национальной культуры; б) усвоению национальных ценностей в системе лексико-семантической системы; в) кодификации этически приемлемых форм самовыражения в обществе, этике дискуссионного общения и этике взаимодействия с представителями национальной культуры.

Применение алгоритма лингвокультурологического анализа лигвокультуремы человек позволяет выделить: 
1) аксиологический уровень, предполагающий усвоение основных ценностно-смысловых и нормативно-регулятивных установок мировой и национальной лингвокультурем для социализации личности в социокультурной действительности, построенной на основе ценностных ориентаций, оказание поддержки в выборе индивидуально значимой аксиологической системы в ситуациях постоянного изменения значимых ценностей;

2) коммуникативный уровень, который предусматривает овладение формами и средствами межкультурной и социальной коммуникации, основными принципами осуществления диалогового (полилогового / межкультурного) общения путем овладения основными его механизмами и кодами в социуме, ориентированными на обеспечение процессов межличностного взаимодействия;

3) субъектно-интериоризационный уровень, который предусматривает овладение средствами личностного развития, языковыми и речевыми умениями и навыками, которые свидетельствуют о социокультурном становлении опыта языковой личности.

\section{Bibliographic references}

AKADEMICHNY ZVOD PRYKAZOK, 1976 [Academic Proverbs Collection] / Prikazki i primovki: u 2 kn. Kn. 1, 2 Minsk: Navuka i ttkhnika, 1976. 358 p.

BYTYKH, A.K. - MOKYENKO, V.M. - STEPANOVA, L.Y. 1998 Slovar' russkoy frazeolohyy [Dictionary of Russian phraseology]: ystoryko-etymolohycheskyy spravochnyk [historical and etymological reference book]. SPb.: Folyo-Press, 1998. $1056 \mathrm{p}$.

VELYKYY TLUMACHNYY SLOVNYK, 2007 suchasnoyi ukrayins'koyi movy [Great explanatory dictionary of modern Ukrainian language] / uklad. i holov. red. V.T. Busel. Kyiv ; Irpin' : VTF «Perun», 2007. 1736 s.

VERBENYETS, M. 2007 Pryntsypy tvorennya suchasnoho dvomovnoho slovnyka yurydychnoyi terminolohiyi [Principles of Creation of Modern Bilingual Dictionary of Legal Terminology] // Visnyk Mizhnarodnoho slov'yans'koho universytetu: Seriya 〈Filolohichni nauky〉. Kharkiv, 2003. T. 6. \# 3. S. 5-7.

ZHAYVORONOK, V. 2006 Znaky ukrayins'koyi etnokul'tury [Signs of Ukrainian ethnoculture]. Slovnyk-dovidnyk [Dictionary-directory] / V. Zhayvoronok. Kyiv, 2006. 704 p.

KRONYK, A.A. 1993 Novye metody psykholohyy zhyznennoho puty [New methods of life path psychology] / A.A. Kronyk. Moskow : Nauka, 1993. 280 p.

LANOVYK, M.B. - LANOVYK Z.B. 2001 Ukrayins'ka narodna tvorchist' [Ukrainian folk art] : pidruchnyk. Kyiv : Znannya-Pres, 2001. $591 \mathrm{~s}$.

LEPESHAY, I.Ya. 2014 Etymalahichny slovnik prykazok [Etymological dictionary of proverbs]. Minsk: Vysheyshaya shkola, 2014. 141 p.

NAUKOVO-PRAKTYCHNYY KOMENTAR 2013 do Kryminal'noho protsesual'noho kodeksu Ukrayiny [Scientific and practical commentary on the Criminal Procedure Code of Ukraine]: [vid 13 kvit. 2012 r.] / [O. A. Banchuk ta in.] ; za red. O. A. Banchuka, R. O. Kuybidy, M. I. Khavronyuka ; Tsentr polit.-prav. reform. Kharkiv : Faktor, 2013. 1058 p.

OZHEHOV, S.Y. - SHVEDOVA, N.Yu. 2010 Tolkoviy slovar' russkoho yazika [Explanatory dictionary of the Russian language]. - Moskow. 2010. T. 1-2.

PRYSSLIV'YA I PRYKAZKY 1989 [Proverbs and sayings] / AN URSR. Instytut mystetstvoznavstva, fol'kloru ta etnohrafiyi im. M.T. Ryl's'koho; upor. M.M. Pazyak; vidpov. red. S.V. Myshanych. Kyiv: Naukova dumka, 1989. 480 s.

RELIHIYEZNAVCHYY SLOVNYK 1996 [Religious dictionary] / [za red. prof. A. Kolodnoho i B. Lobovyka]. - K. : Chetverta khvylya, 1996. 390 p. 
RUSSKYE PJSLOVYTSY Y POHOVORKY 1988 [Russian proverbs and sayings] / pod red. V. Anykyna; predys. V. Anykyna; sost. F. Selyvanov; B. Kyrdan; V. Anykyn. M. : Khudozh. lyt., 1988. 431 p.

SKAB, M.V. 2003 Semantychna struktura slova dusha v suchasniy ukrayins'kiy movi [The semantic structure of the word soul in the modern Ukrainian language] / M.V. Skab // Naukovyy visnyk Chernivets'koho universytetu. - Slov'yans'ka filolohiya : [zb. nauk. prats']. Vyp. 170-171. Chernivtsi, 2003. p. 92-96.

FYLOSOFSKYY ENTSYKLOPEDYCHESKYY SLOVAR' 1989 [Philosophical Encyclopedic Dictionary] / redkol.: S.S. Averyntsev, Э.A. Arab-Ohly, L.F. Yl'ychev. M. : Sov. Entsyklopedyya, 1989. 815 p.

YURKEVYCH, P.D. 1990 Serdtse y eho znachenye v dukhovnoy zhyzny cheloveka, po uchenyyu slova Bozhyya [The heart and its meaning in the spiritual life of man, according to the teaching of the word of God] / P.D. Yurkevych // Fylosofskye proyzvedenyya. Moskva : Pravda, 1990. S. 69-104.

BARTMINSKI, J. 1985 Stereotyp jako przedmiot lingwistyki (1) / Z problemow frazeologii polskiej i slowianskiej. - Warszawa, 1985. T. III. $68 \mathrm{s.}$

DEETZ, S. 1984 Metaphor analysis // Methods for intercultural communication research. Beverly Hills, 1984. p. 117-132.

GAJDA, STANISLAW 1992 Stylistics today // Stylistyka I. Stylistyka dzis. Warsaw. Cracow. Opole: Polish academy of sciences. Pedagogical university, 1992. p. 5-14.

HIRSCH, E.D. 1987 Cultural Literacy, What Every American Needs to Know. Vintage Books, 1987. P.3. 46 p.

INTERCULTURAL SOURCEBOOK 1995 : Cross Cultural Training Methods. V.1. / Ed. by M. Flower. - Yarmouth: Intercultural Press, 1995. 230 p.

JOHNSON-LAIRD, P.N. 1986 Conditionals and mental models // On conditionals. Cambridge, 1986. 9. 82-91.

LADO, R. 1957 Linguistics Across Cultures. Applied Linguistics for Language Teachers. - Ann Arbor: University of Michigan Pres, 1957. 127 p.

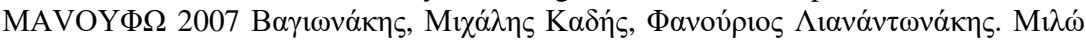

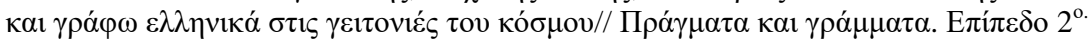

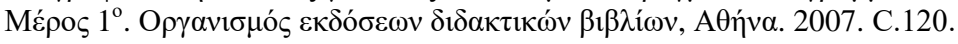

SAPIR, E. 1978 Language / E. Sapir // Encyclopedia of the social sciences. - New York, 1978. P. 155-169.

Words: 6376

Characters: 527000 (31 standard pages)

Prof. Tetiana M. Mishenina,

Doctor of Pedagogic Sciences, Associate Professor,

Professor at the Department of Ukrainian language

Kryvyi Rih State Pedagogical University

54, Gagarina St., 50000, Kryvyi Rih,

Ukraine

t.mishenina@gmail.com

Associate Professor, Larisa S. Dsevickaya,

Candidate of Pedagogic Sciences,

the Department of foreign and Ukrainian business languages

Kryvyi Rih Economic Institute Kyiv National Economic University of Vadim Hetman 64, Poshtoviy Pr. 50000, Kryvyi Rih,

Ukraine

dsevickayalarissa@mail.ru

XLinguae, Volume 10, Issue 4, October 2017, ISSN 1337-8384, eISSN 2453-711X 